\title{
Nutrient availability in phosphate and potassic rocks induced by Acidithiobacillus oxidizing bacteria to produce biofertilizers
}

\section{Emmanuella Vila Nova da Silva*, Newton Pereira Stamford, Wagner da Silva Oliveira, Valdomiro Severino de Souza Júnior, Lusiene Barbosa Sousa, Mario de Andrade Lira Junior}

\author{
Federal Rural University of Pernambuco - Department of Agronomy, Av. Dom Manoel de Medeiros, s/n - 52171- \\ 900, Recife-PE, Brazil
}

*Corresponding author: manuvilanova@yahoo.com.br

\begin{abstract}
Production of conventional fertilizers requires significant energy consumption which increases the price of the product. In recent years, a growing interest on the application of natural products has been shown by public. The aim of this work is to evaluate the effectiveness of the sulfur bacteria Acidithiobacillus thiooxidans to promote mineralogy changes and increase nutrient availability, using phosphate and potassic rocks to produce PK biofertilizers. The study was set up in Petri dishes using $30 \mathrm{~g}$ of phosphate rock + $30 \mathrm{~g}$ of potassium rock, each rock mixed with elemental sulfur applied at two levels $10 \%$ and $20 \%(3 \mathrm{~g}$ and $6 \mathrm{~g}$ ) in dish. The experiment was conducted in a completely randomized design with eight replications (each rock). The bacterium was inoculated applying $1 \mathrm{ml}$ per g of elemental sulfur. The rocks were incubated during 180 days and mineralogical analysis by XRD and chemical analysis were processed at 30,60,120, 150 and 180 days after inoculation. The Acidithiobacillus produced sulfuric acid, which promoted mineralogical changes especially at 180 days after inoculation, compared with the initial time. The inoculation of Acidithiobacillus reduced $\mathrm{pH}$ and promoted mineralogical changes in $\mathrm{P}$ and $\mathrm{K}$ rocks with a significant increase in $\mathrm{P}$ and $\mathrm{K}$ availability, becoming a viable alternative to plant nutrition instead of soluble PK fertilizers. In addition, it showed great potential for a sustainable agriculture system.
\end{abstract}

Keywords: Acidithiobacillus thiooxidans; biotite; elemental sulfur; powdered rock; X-rays diffraction.

Abbreviations: Ac_Acidithiobacillus thiooxidans; PR_phosphate rock; KR_potassic rock; PB_Biofertilizer from phosphate rock; KB_Biofertilizer from potassic rock, XRD_X-rays diffraction.

\section{Introduction}

To increase crop yield, the application of soluble fertilizers has been one of the most used agricultural practices. The use of natural rocks applied in fertilization has not been well-studied due to the low availability of nutrients and renewable sources of natural products, which are absolutely necessary for the rational use of fertilizers in agriculture (Araujo et al., 2009).

The inclusion of rocks as effective sources of nutrients for plants requires modification of physical, chemical or biological processes, because nutrients are not readily available in soils (van Straaten, 2007). Thus, microorganisms that have the ability to solubilizing phosphate and potassic rocks are very important in sustainable agriculture. The oxidizing bacteria Acidithiobacillus thiooxidans is able to metabolically produce sulfuric acid $\left(\mathrm{H}_{2} \mathrm{SO}_{4}\right)$, which reduces $\mathrm{pH}$ (El Tarabily et al., 2006) and may promotes the availability of nutrients (Stamford et al., 2016; Oliveira et al., 2017; Silva Júnior et al., 2018). The use of powdered rocks may reduce the application of soluble fertilizers and the production of rock biofertilizers, which is a practical process and requires low energy consumption (Lima et al., 2010).
Natural phosphate is originated from igneous or metamorphic rocks and exhibit low reactivity and low solubility in water and acid solutions. The sedimentary material exhibits high reaction with isomorphic compounds for replacement in their structures to reach greater reactivity (Soares et al., 2000; Horta, 2015).

Brazilian soils have low amount of phosphorus which generally is not present in available forms. It is due to its high phosphate fixing capacity by the adsorption and precipitation of phosphate that is adsorbed on surfaces of soil particles or precipitate to form calcium, magnesium, iron or aluminum phosphate (Fink et al., 2016; Santos et al., 2016).

Biotite, mineral of the mica group is common in soils and igneous rocks comprise the original source of mica (Kämpf et al., 2009). More than $90 \%$ of the potassium soluble fertilizer used in Brazilian agriculture is purchased from the international companies, because the production does not satisfy the great demand (Barbosa Filho et al., 2007; Santos et al., 2015). Due to importance of soluble fertilizers for increasing plant yield, studies are needed to develop 
biofertilizers that can serve as alternatives for $\mathrm{P}$ and $\mathrm{K}$ sources (Duarte et al., 2012).

A method for reducing the cost of fertilization is the use of slow-release rocks, such as natural phosphate, biotite and other K-rich rocks, as well as ground basalt, which are inoculated with specific microorganisms that produce strong acid. Studies on sulfur inoculated with Acidithiobacillus showed that this specific bacterium is very efficient in the oxidation of elemental sulfur to produce sulfuric acid, which can increase the nutrient availability from phosphate and potassium rocks (Stamford et al., 2015, 2016).

Biofertilizers from phosphate and potassium rocks mixed with sulfur inoculated with Acidithiobacillus have been applied with excellent results in different Brazilian soils of the rainforest zone and the semiarid region, grown with various crops (Oliveira et al., 2014, 2017; Stamford et al., $2009,2015,2016)$. However, no literature explains the specific reactions and mineralogical changes occurred during the process of rock biofertilizer production to release the minerals and interactions in availability of the nutrients.

In this experiment, we aim to evaluate the effectiveness of biofertilizer produced from phosphate and potassium rocks mixed with elemental sulfur inoculated with $A$. thiooxidans in laboratory to identify the formed minerals. In addition, the nutrient availability was evaluated. For this purpose, two levels of sulfur (10 and 20\%) corresponding to rocks amounts in mineralogical and chemical analysis at incubation times (0 to 180 days) were evaluated. We hypothesized that the phosphate and potassium rocks with elemental sulfur inoculated with $A$. thiooxidans produces PK biofertilizers which promotes mineralogical changes and increase nutrient availability. Moreover, the sulfur high level in the presence of greater quantity of oxidizing bacteria will promote a greater mineralogical change and greater nutrient availability.

\section{Results}

\section{Mineralogical analysis}

The effect of the sulfur inoculated with the oxidative bacteria $A$. thiooxidans (strain FG01) on X-rays diffraction (XRD) patterns of the phosphate rock at zero and 180 days incubation incubation at level 2 are presented in Fig. 1. The samples from 30 to 150 days did not show effects of the treatments and no difference between two levels was observed.

The XRD patterns of phosphate rock (PR) at zero incubation time and phosphate biofertilizer (PB) produced with rock phosphate + elemental sulfur $(6 \mathrm{~g})+A$. thiooxidans at 180 days of incubation showed that the mineral was hydroxyapatite.

The hydroxyapatite was identified by basal spacing peaks at $0.344,0.281,0.277$ and $0.271 \mathrm{~nm}$, which expressively reduced their intensity in the treatment after 180 days and indicated a strong alteration of the mineral in this period. Consequently, there was an increasing of available phosphorus (Fig. 4) and exchangeable calcium (Fig. 6). Hydroxyapatite is calcium phosphate that may release available $\mathrm{P}$ and $\mathrm{Ca}$. In the exchangeable complex, calcium sulphate (gypsum) was identified in the diffractometry peaks of $0.760,0.428$ and $0.286 \mathrm{~nm}$, which significantly increased in the treatment with 180 days of incubation.
The mineralogy analysis of the potassic rock (KR) at zero incubation time and the potassic biofertilizer (KB) and powdered potassic rock and sulfur $(6 \mathrm{~g})$ inoculated with $A$. thiooxidans at 180 days identified the minerals biotite, gypsum and goethite (Fig. 2).

The biotite in $K R$ and $K B$ was identified by presence of diffraction peaks relating to basal spacings at $1.00,0.50$ and $0.334 \mathrm{~nm}$, and the identification of goethite was performed by the peaks of 0.418 and $0.269 \mathrm{~nm}$.

After 180 days, a substantial amount of well-crystallized biotite remains (peaks of 1.00 and $0.334 \mathrm{~nm}$, according to characteristic of biotite) was identified, demonstrating a slight change in this mineral.

\section{$p H$ and available $P$ and $K$}

A significant difference in the $\mathrm{pH}$ values was observed in phosphate and potassic rocks, at zero incubation time, compared with the others times of incubation (Fig. 3).

A short variation of the treatments with the sulfur levels ( $3 \mathrm{~g}$ and $6 \mathrm{~g}$ ) was observed. The phosphate and the potassic rocks showed a pH near 7.0 at zero incubation time, with a significant decrease to approximately 3.0 using both rocks in the incubation times from 30 to 180 days.

In reference to available $P$, the results revealed the potential of phosphate rock (PR) and the biofertilizer from phosphate rock $(\mathrm{PB})$ mixed with sulfur and inoculated with the oxidizing bacteria $A$. thiooxidans (Fig. 4). The sulfur bacteria promoted a significant increase in available $P$ from time zero to 30 days of inoculation due to the production of $\mathrm{H}_{2} \mathrm{SO}_{4}$, which was sufficient for solubilizing $\mathrm{P}$ from the phosphate rock. However, the increase in available $P$ continued during the incubation times in low proportion and without a significant difference by the applied sulfur levels ( $3 \mathrm{~g}$ and $6 \mathrm{~g}$ ). From 150 days to 180 days of incubation, a slight decrease without significant difference was observed.

The biofertilizer that was produced from potassic rock (KB) showed a significant increase in the available $K$ and revealed a substantial difference when incubated for 150 days and with sulfur ( $3 \mathrm{~g}$ and $6 \mathrm{~g}$ ), compared with potassic rock at time zero (Fig. 5). The rates of sulfur ( $3 \mathrm{~g}$ and $6 \mathrm{~g}$ ) did not significantly affect difference but showed an increase of $41 \%$ and $58 \%$ at time zero and 150 days of incubation, respectively.

\section{Exchangeable $\mathrm{Ca}$ and $\mathrm{Mg}$}

The results of exchangeable $\mathrm{Ca}$ in the phosphate rock biofertilizer (PB) are presented in Fig. 6 . The phosphate rock biofertilizer significantly promoted available $P$ and exchangeable $\mathrm{Ca}$. The increment in calcium concentration improved the potential of the phosphate rock biofertilizer produced with elemental sulfur inoculated with $A$. thiooxidans.

Expressive values of exchangeable Ca were obtained using the rock phosphate biofertilizer. The potassic rock biofertilizer contributed a small portion of the exchangeable Ca (approximately $10 \%$ compared with the phosphate rock).

The exchangeable $\mathrm{Ca}$ was increased during the incubation period to a maximum value $\left(108 \mathrm{cmol}_{\mathrm{c}} \mathrm{dm}^{-3}\right)$ at 150 days in the treatments with sulfur $(3 \mathrm{~g})$ and $(6 \mathrm{~g})$. Both sulfur levels showed a great difference comparing with the zero time incubation $\left(0.20 \mathrm{cmol}_{\mathrm{c}} \mathrm{dm}^{-3}\right)$. However, no significant 
difference was observed between the two sulfur levels. Moreover, in 180 days of incubation a decrease in exchangeable Ca was occurred, compared with 150 days. In reference to the exchangeable Mg in potassic rock (Fig. 7) we observed significant effectiveness in the different incubation times. It was a greater increase when the potassic rock was incubated at 150 days with sulfur level 6 g), compared to others incubation times in the same sulfur concentration. Additionally, difference of sulfur levels ( $3 \mathrm{~g}$ and $6 \mathrm{~g}$ ) inoculated with $A$. thiooxidanswas was observed between time zero and the incubation at the different days.

\section{Discussion}

Apatite is a none silicate mineral most abundant in soil and it has the general formulation $\mathrm{Ca}_{5}\left(\mathrm{PO}_{4}\right)_{3}(\mathrm{OH}, \mathrm{F}, \mathrm{Cl})$. By substituting the ions $\mathrm{F}^{-} \mathrm{Cl}^{-}$and $\mathrm{OH}^{-}$in accordance with the accompanied anion, the following materials may form: fluorapatite $\left(\mathrm{Ca}_{10}\left(\mathrm{PO}_{4}\right)_{6} \mathrm{~F}_{2}\right)$, chlorapatite $\left(\mathrm{Ca}_{10}\left(\mathrm{PO}_{4}\right)_{6} \mathrm{Cl}_{2}\right)$, and hydroxyapatite $\left(\mathrm{Ca}_{10}\left(\mathrm{PO}_{4}\right)_{6}(\mathrm{OH})_{2}\right)$ (Melo et al., 2009). The current observed that the hydroxyapatite was the principal identified mineral, and the occurrence of gypsum, is a result of sulfur oxidation by $A$. thiooxidans and its reaction with calcium released changing the hydroxyapatite. Various researchers suggest that the most important factor to affect the hydroxyapatite solubility is the acidity. According to Santos (2013), the hydroxyapatite is soluble in acid solutions and insoluble in alkaline solutions. Klein et al. (1990) analyzed samples of calcium phosphate, including hydroxyapatite and observed a reduction when the $\mathrm{pH}$ in the medium increased.

Moore and Reynalds (1989) reported that the intensity of the peak at 0.5 is smaller than half the intensity of the peak at 1.00. It is characteristic of octahedral ferric micas.

After 180 day if incubation with A. thiooxidans, there has been little change in the intensity of the peaks relating to the biotite. However, it has been observed that the presence of goethite $(\mathrm{FeO}(\mathrm{OH}))$, an iron oxyhydroxide, is attributed to biotite alteration, because it's a trioctahedral mica with the octahedral sheet occupied by divalent cations as $\mathrm{Mg}^{2+}$ or $\mathrm{Fe}^{2+}$ (Dixon, 1989). It generates iron oxides and releases $\mathrm{Mg}$, $\mathrm{Fe}$ and $\mathrm{Ca}$, among other elements.

In the weathering process, the mica releases $\mathrm{K}^{+}$with higher amounts of trioctahedral mica (biotite) and lower amounts of dioctahedral mica (muscovite) (Kämpf et al., 2009).

The cation exchange capacity (CEC) may increase in low amounts because goethite is formed in this stage, which increases $\mathrm{pH}$ (acidity). The charge of this mineral is dependent on $\mathrm{pH}$, which is positive in acidic $\mathrm{pH}$ because the point of zero charge $(\mathrm{PZC})$ in this mineral is 8.5. The main mineral (biotite) has gradually changed. If $\mathrm{K}$ of biotite were completely available, it may leach during the rainy season and the plants would not be able to absorb it.

Besides the release of iron, biotite alteration mainly promotes the release of potassium, magnesium and other alkaline earth metals, such as calcium, the element that is present in biotite (Dixon, 1989). The current study showed specially an increasing of potassium, calcium and magnesium exchangeable after 180 days of incubation (Fig. 5, 6 and 7, respectively).

The $\mathrm{K}$ liberated by the biotite is present in the interlayer of the crystal. The $\mathrm{K}$ is released from the following acidic reaction: $\mathrm{KSiAlOMgFeOH}+\mathrm{H}$ (acid) $+\mathrm{H}_{2} \mathrm{O} \rightarrow \mathrm{FeOOH}$ (goethite) + SiAlOOH (kaolinite) + Mg, Fe and $\mathrm{Ca}$. The reaction occurs when the $\mathrm{pH}$ in the soil solution is very acidic $(\mathrm{pH}<5.5)$. In the biofertilizers from the rocks, the $\mathrm{pH}$ is very low (3.0-3.5) due to the metabolic reaction produced by $A$. thiooxidans $\left(\mathrm{S}^{\mathrm{O}}+\mathrm{H}_{2} \mathrm{O}+1.5 \mathrm{O}_{2} \rightarrow \mathrm{H}_{2} \mathrm{SO}_{4}\right)$, which promotes the solubilization of the elements in the minerals (Stamford et al., 2011). However, a substantial amount of biotite needs to be modified.

The presence of gypsum in the samples after 180 days of treatment may be referred to the impurity or may also have formed from the oxidation of sulfur and its reaction with the calcium released from biotite.

Despite the fact that biotite alteration has contributed to availability of potassium, calcium and magnesium, it is important to note that large amounts of biotite remained as residue biofertilizer, becoming a large mineral reserve of the soil.

The $\mathrm{pH}$ revealed the effectiveness of the $A$. thiooxidans, which metabolically produced sulfuric acid $\mathrm{H}_{2} \mathrm{SO}_{4}$ and promoted a significant difference in both rocks.

Stamford et al. (2004) applied natural phosphate from Gafsa (Tunisia) and elemental sulfur. They observed a significant difference in $\mathrm{pH}$ values without inoculation and inoculated with the sulfur oxidizing bacteria Acidithiobacillus, 60 days of incubation. The effect on $\mathrm{pH}$ value was probably lower because the Gafsa phosphate significantly differed from the natural phosphate (Irecê - BA) that was employed in the current study. Furthermore, the reduction may be influenced by the strain of $A$. thiooxidans (FG 01), which is more effective and seems to be the main factor responsible for the acidification process promoting values of $\mathrm{pH}$ lower than 4.0 .

Stamford et al. (2013) in a Neosoil Fluvic Sodic grown with cowpea reported a reduction in soil pH from 10.5 to 8.00 . Stamford et al. (2015) with cowpea in a saline sodic soil of the Brazilian Semiarid region demonstrated a reduction in soil $\mathrm{pH}$ when sulfur inoculated with Acidithiobacillus was applied at a rate of $3.2 \mathrm{t} \mathrm{ha}^{-1}$.

Stamford et al. (2004) evaluated the effect of biofertilizer from phosphate rock with sulfur inoculated with Acidithiobacillus. They observed the effect of the sulfuric acid on available $P$ at different times of incubation. Similar results were reported by Stamford et al. (2015), who evaluated the effect of different rates of rock biofertilizer and sulfur inoculated with $A$. thiooxidans in an acid soil with a low availability of $P$.

Lima et al. (2007) employed rock biofertilizer produced with natural phosphate and biotite and sulfur inoculated with $A$. thiooxidans, applied in a mixture with earthworm compost. They observed the effectiveness of $P$ and $K$ fertilization in increasing the available $P$ and $K$ in soil with the application of different rates. Stamford et al. $(2013,2015)$ suggested that the biofertilizers that were produced from phosphate and potassic rocks and sulfur inoculated with $A$. thiooxidans may be alternative for soluble fertilizers in soil with a low availability of $\mathrm{P}$ and $\mathrm{K}$.

The increase in available $K$ may be explained by the solubilisation of the elements in the biotite employed for production of the potassic rock biofertilizer. The effect is probably attributed to the sulfuric acid that was produced by the metabolic reaction facilitated by the oxidizing bacteria $A$. thiooxidans in the presence of elemental sulfur. These 


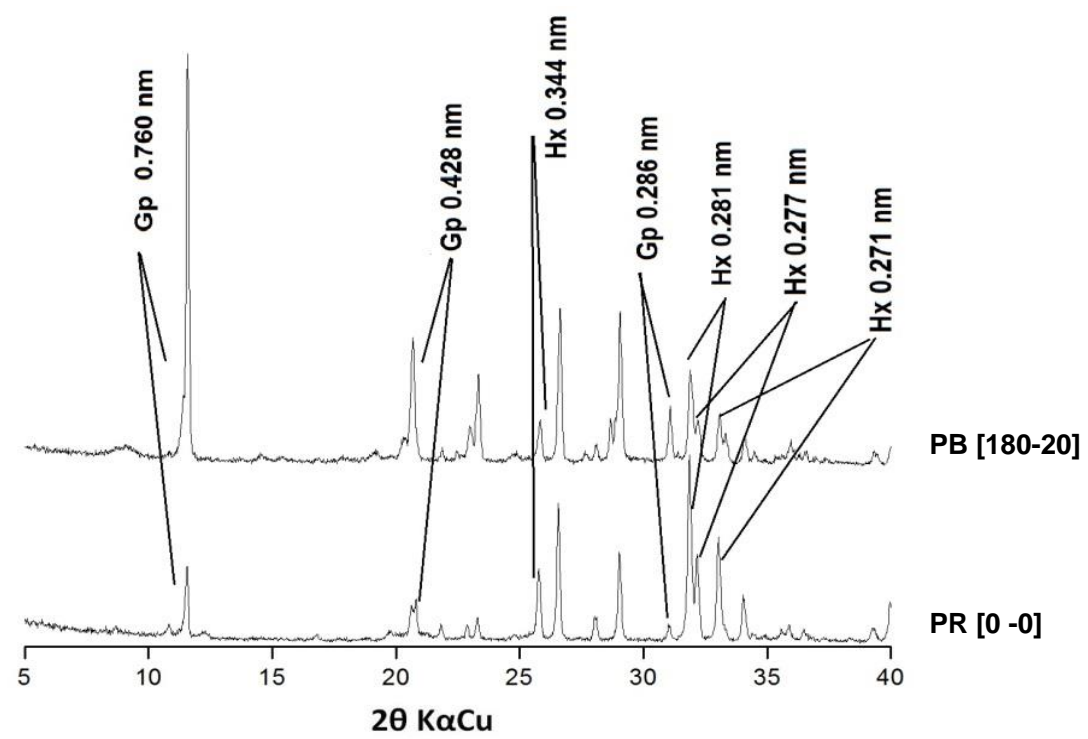

Fig 1. XRD patterns of the phosphate rock (PR) at time zero, without sulfur, and with addition of Acidithiobacillus thiooxidans (FG01) to produce phosphate rock biofertilizer (PB) with sulfur $(6 \mathrm{~g})$ inoculated with $A$. thiooxidans, after 180 days of incubation. $\mathrm{Gp}=$ gypsum; $\mathrm{Hx}=$ hydroxyapatite.

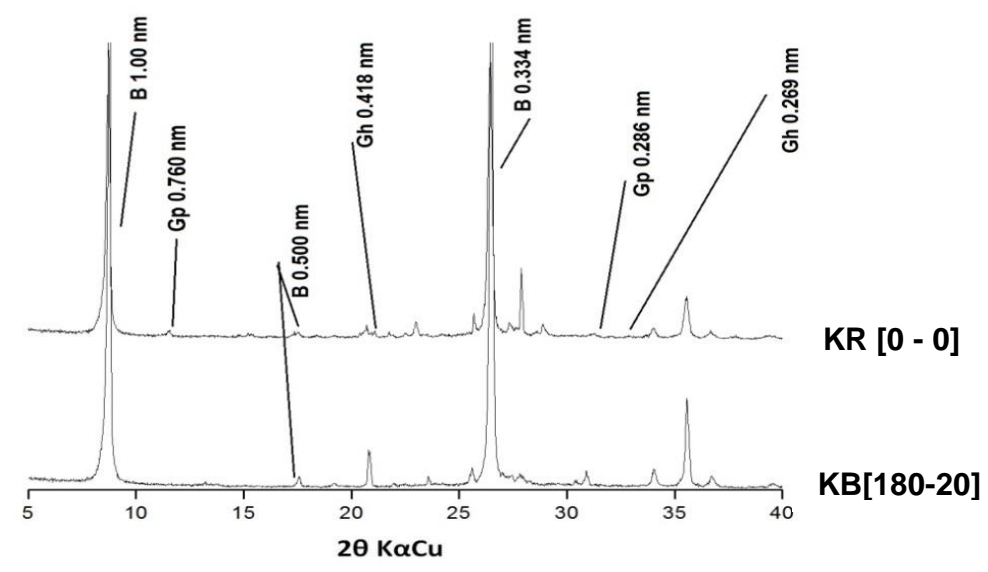

Fig 2. XRD patterns of the potassic rock (KR) at time zero, without sulfur, and with addition of Acidithiobacillus thiooxidans (FG01) to produce potassic rock biofertilizer (KB) with sulfur $(6 \mathrm{~g})$ inoculated with $A$. thiooxidans, after 180 days of incubation. $B=$ biotite; $\mathrm{Gp}=$ gypsum; $\mathrm{Gh}=$ goethite.

results indicate the potential of the potassic rock (RK) mixed with sulfur inoculated with the oxidizing bacteria to increase the potassium availability.

Stamford et al. (2016) observed a significant increase in the available $\mathrm{K}$ when applied PK biofertilizers. In addition, it is important to describe the residual effect of these PK source in the two consecutive crop harvests.

In 180 days incubation, the decrease in exchangeable Ca was probably due to the increase in the immobilization facilitated by the microorganisms involved in the process, opposite to the 150 days which showed an increase in exchangeable calcium. Stamford et al. (2011), evaluated the effects of rock biofertilizers on yield and nutrient absorption of grapes using soluble fertilizers and powdered rocks. They observed the effectiveness of the bacteria $A$. thiooxidans to increase the solubilization of Ca contained in the phosphate rock.

Positive and significant effect for exchangeable $\mathrm{Mg}$ was observed by Stamford et al. (2009) and by Oliveira et al. (2014) when applied phosphate and potassic rock biofertilizers in Argisol of the Brazilian semiarid region, especially using higher rates of potassic rock biofertilizer. Stamford et al. (2014) reported effectiveness of availability of $\mathrm{Mg}^{+2}$ when applied the phosphate and potassic rock biofertilizer on grape grown in a soil of the semiarid region of the San Francisco Valley, mixed with organic matter (earthworm compost) and $\mathrm{pH}$ equivalent to 7.9 that neutralized the rock biofertilizer acidity. These results confirm the effect of the sulfur oxidizing bacteria which promote acidity and release nutrients of rocks, in this case is referent to exchangeable $\mathrm{Mg}^{+2}$ contained in the biotite rock. 
$\because \mathrm{g} \mathrm{S} \mathrm{S}^{\circ} \quad 6 \mathrm{~g} \mathrm{~S}$

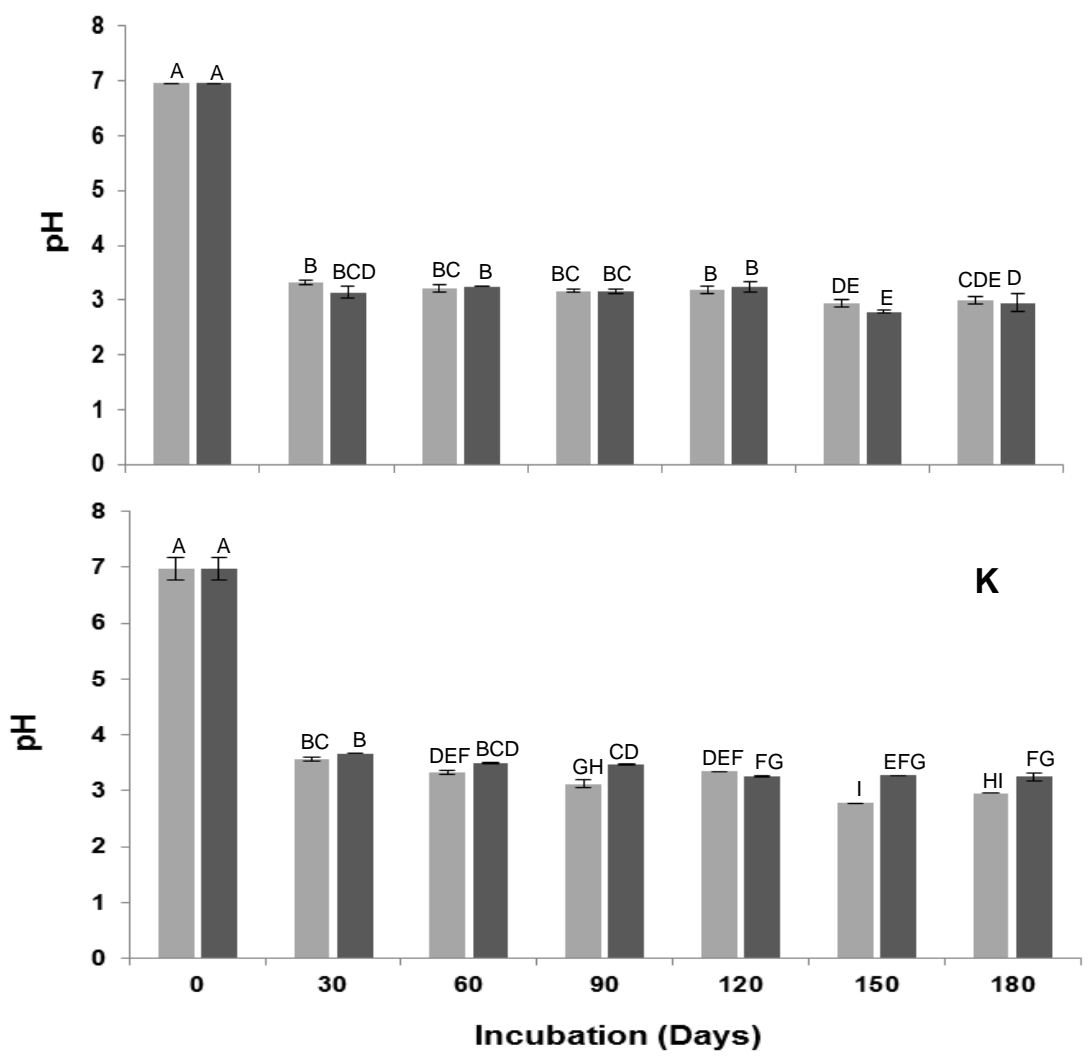

Fig 3. Effect on the pH of the phosphate rock (PR) and potassic rock (KR) at zero and different incubation times $(30,60,90,120,150$ and 180 days) with rocks and sulfur $(3 \mathrm{~g}$ and $6 \mathrm{~g}$ ) inoculated with $A$. thiooxidans (FG01). *Data with the same letters are not different by the Tukey test $(P<0.05)$.

\section{$\because 3 \mathrm{~g} S^{\circ}=6 \mathrm{~g} \mathrm{~S}$}

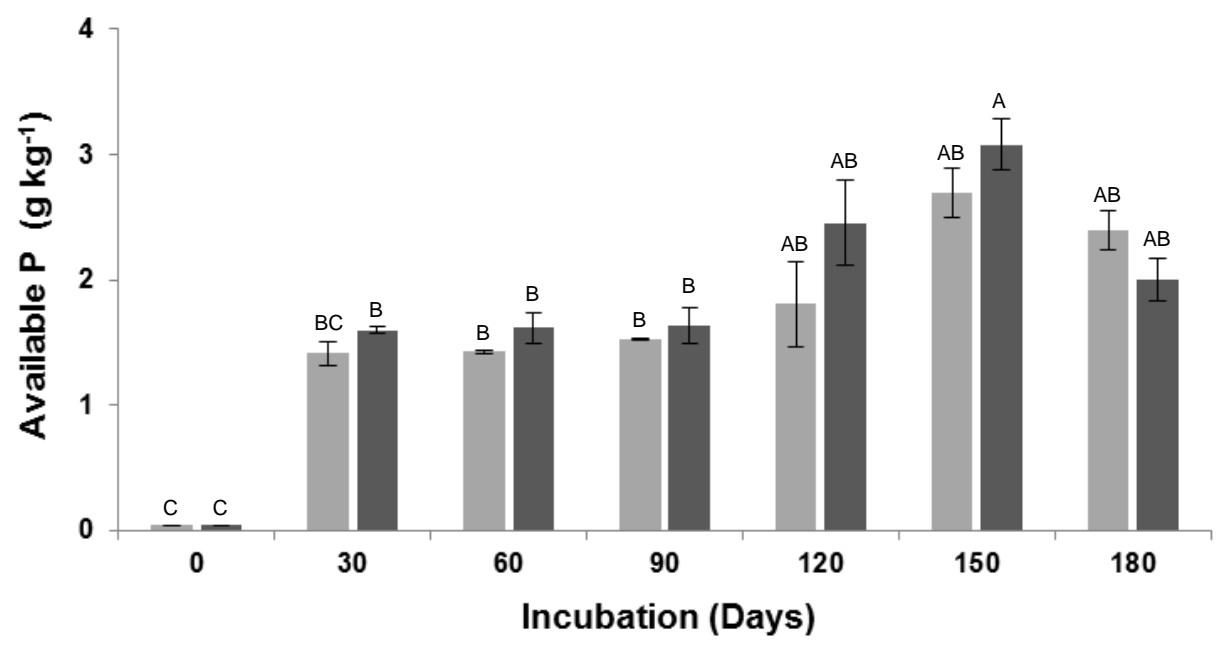

Fig 4. Available $P$ in the phosphate rock (PR) at zero time incubation and in the phosphate biofertilizer (PB) and sulfur ( $3 \mathrm{~g}$ and $6 \mathrm{~g})$ inoculated with $A$. thiooxidans (FG01) at different times of incubation (30,60, 90, 120, 150 and 180 days). *Data with the same letters are not different by the Tukey test $(P<0.05)$. 


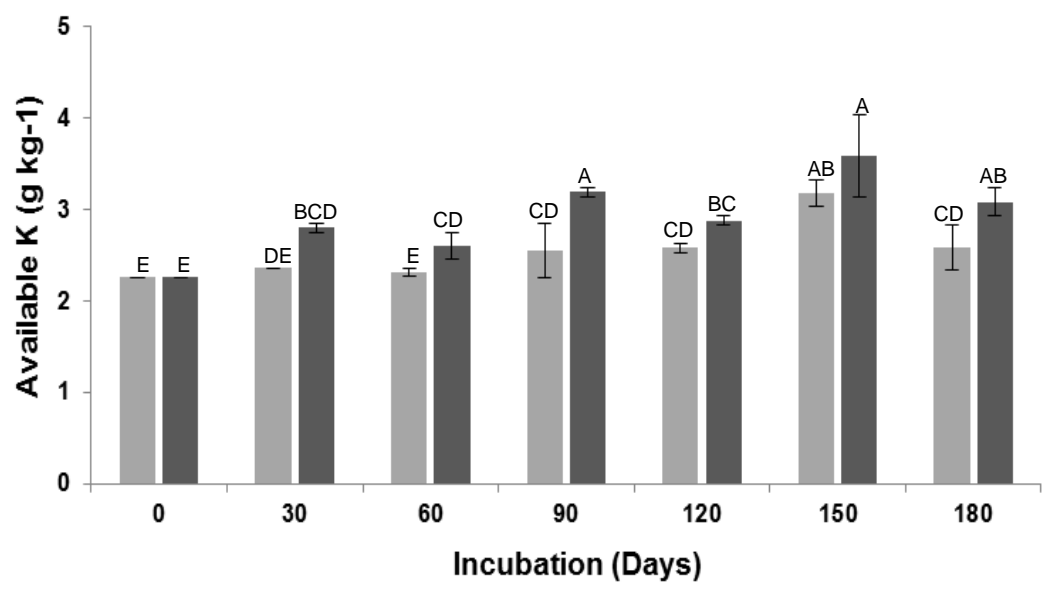

Fig 5. Available $\mathrm{K}$ in the potassic rock (KR) at zero time incubation and potassic biofertilizer (KB) with sulfur ( $3 \mathrm{~g}$ and $6 \mathrm{~g}$ ) inoculated with $A$. thiooxidans (FG01) at different times of incubation $\left(30,60,90,120,150\right.$ and 180 days). ${ }^{*}$ Data with the same letters are not different by the Tukey test $(P<0.05)$.

$=3 \mathrm{~g} \mathrm{~S}=6 \mathrm{~g} S^{\circ}$

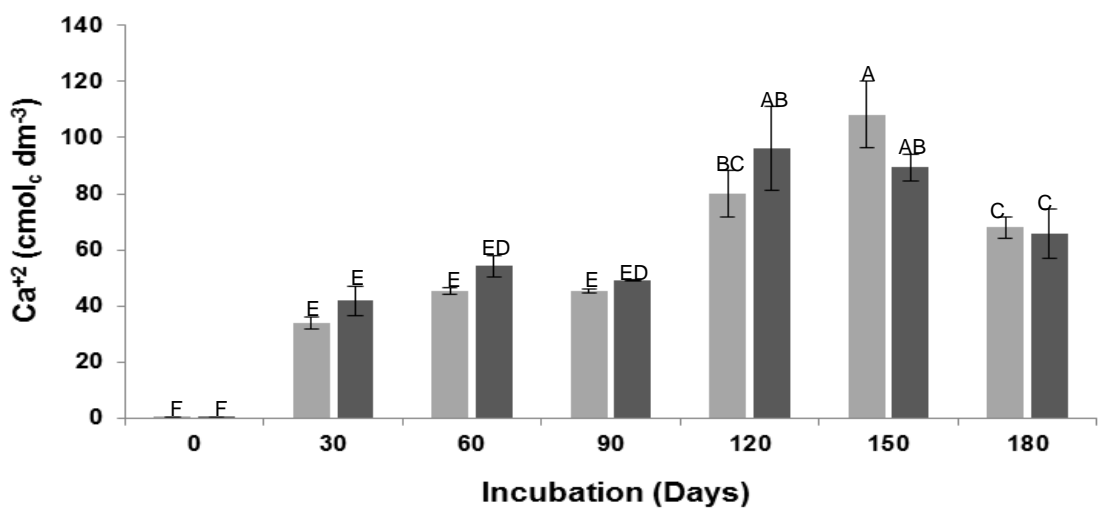

Fig 6. Exchangeable $\mathrm{Ca}$ in the phosphate rock at zero time incubation without inoculation and at different times of incubation and sulfur ( $3 \mathrm{~g}$ and $6 \mathrm{~g}$ ) inoculated with $A$. thiooxidans (FG01) after 180 days of incubation at different times $(30,60,90,120,150$ and 180 days). *Data with the same letters are not different by the Tukey test $(P<0.05)$.

$=3 g S^{\circ}=6 g S^{\circ}$

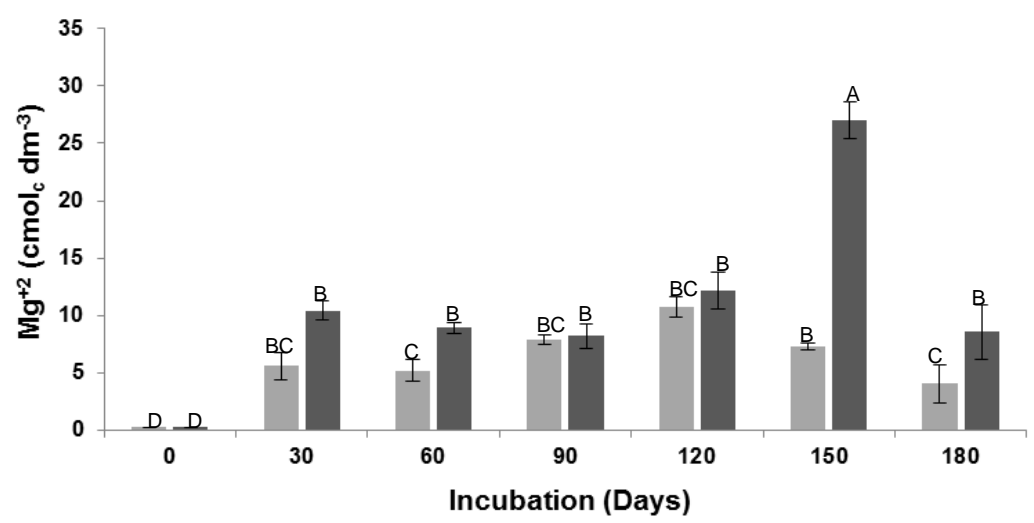

Fig 7. Exchangeable $\mathrm{Mg}$ in the potassic rock at zero and different times of incubation without inoculation and sulfur ( $3 \mathrm{~g}$ and $6 \mathrm{~g})$ inoculated with $A$. thiooxidans (FG01) after 180 days of incubation at different times (30,60, 90, 120, 150 and 180 days). *Data with the same letters are not different by the Tukey test $(P<0.05)$. 


\section{Materials and methods}

\section{Characteristics of rocks and bacterial growth}

The rocks employed in the study were: (a) natural phosphate (Irece - BA), Brazil, $24 \%$ total $\mathrm{P}\left(\mathrm{P}_{2} \mathrm{O}_{5}-\right.$ Phosphorus pentoxide) and $32-36 \%$ total $\mathrm{Ca}$ ( $\mathrm{CaO}$ - Calcium oxide); (b) biotite (Santa Luzia - PB), Brazil, 8-10\% total K $\left(\mathrm{K}_{2} \mathrm{O}-\right.$ Potassium oxide) and $15-22 \%$ total $\mathrm{Mg}$ (MgO - Magnesium oxide).

The oxidizing bacteria Acidithiobacillus thiooxidans (strain FG01) culture was grown in a specific medium (El Tarabily et al. 2006) sterilized in a vertical autoclave $\left(120^{\circ} \mathrm{C}, 101 \mathrm{KPa}\right)$ for $20 \mathrm{~min}$. The material was mixed in a $125 \mathrm{ml}$ Erlenmeyer flask with $50 \mathrm{ml}$ of medium inoculated with the oxidizing bacteria; shaken at $150 \mathrm{rpm}$ for 20 days at $28 \pm 2^{\circ} \mathrm{C}$.

\section{Experiment conduction and treatments}

The experiment was set up in Petri dishes using $30 \mathrm{~g}$ of powdered phosphate rock (PR), 30g of potassium rock (KR), each rock mixed with elemental sulfur in a completely randomized design with eight replicas (each rocks). The sulfur (S) treatment with two levels $10 \%$ and $20 \%$ (3 g and 6 $\mathrm{g}$ ), inoculated with $A$. thiooxidans (Ac.) and a control treatment (without the addition of $S$ and uninoculated). The bacterium (viable cell concentration $10^{6} \mathrm{ml}^{-1}$ ) was inoculated applying $1 \mathrm{ml}$ per $\mathrm{g}$ of elemental sulfur (Stamford et al., 2016).

The treatments with each rock ( $P R$ and $K R$ ) were: $T 1$ treatment contained $10 \%$ sulfur and Ac. $(3 \mathrm{~g}+3 \mathrm{ml}) ; \mathrm{T} 2$ treatment contained $20 \%$ sulfur and Ac. $(6 \mathrm{~g}+6 \mathrm{ml})$ and T3 treatment without the addition of $S$ and uninoculated with A. thiooxidans. For both rock biofertilizers, filtrate water was applied daily to maintain humidity at approximately $80 \%$ of maximal retention for 180 days.

Samples were collected during the different periods of incubation $(0,30,60,90,120,150$ and 180 days) that were maintained at room temperature, passed through a sieve $(2$ $\mathrm{mm}$ ) and stored in Falcon tubes for mineralogical and chemical analysis. After this, mineralogical identification (Xrays) was performing using diffractometry. To determine the available nutrients $(\mathrm{P}, \mathrm{K}, \mathrm{Ca}$, and $\mathrm{Mg}$ ) the chemical analysis was performed (Embrapa, 2009).

\section{Mineralogical identification of $P$ and $K$ rock biofertilizers}

The mineralogical analysis was carried out in rock samples with elemental sulfur (10 and $20 \%$ ) inoculated with the oxidative bacteria $A$. thiooxidans. The samples were collected at time zero (TO - phosphate or potassic rock) and after 180 days of incubation (rock biofertilizers).

The XRD analysis was done on random powder mounts of phosphate rock - PR (natural phosphate), potassic rock - KR (biotite shist) and in the $P$ and $K$ rock biofertilizers. The sample was scanned from 3 up to $60^{\circ} 2 \theta$ with speed of $1^{\circ} 2 \theta$ $\mathrm{min} / 1$. The XRD pattern was obtained by Shimadzu XRD 6000 (Shimadzu, Tokyo, Japan), applying Cu-K $\alpha$ radiation, and operated on $40 \mathrm{kv} / 30 \mathrm{~mA}$ with a graphite coupled monochromator.

The criteria used for interpretation of XRD patterns and identification of minerals were based on the interplanar spacing (d) as disclosed by Brown and Brindley (1980), and Moore and Reynolds (1989).

\section{Chemical analysis}

The phosphate rock, potassic rock, $\mathrm{P}$ and $\mathrm{K}$ biofertilizers of different treatments and collected at various incubation times and then submitted to the following chemical analysis: $\mathrm{pH}$ (water $-\mathrm{H}_{2} \mathrm{O}$ ) by potentiometry using a $\mathrm{pH}$ meter; available $\mathrm{P}$ and $\mathrm{K}$ (Mehlich 1 ) and exchangeable $\mathrm{Ca}$ and $\mathrm{Mg}$ extracted by $\mathrm{KCl}$ (Potassium chloride) solution in accord with Embrapa (2009).

\section{Statistical analysis}

The chemical results were analyzed using the SAS Program (SAS Institute 2011), and an ANOVA was performed using the Tukey test $(P<0.05)$ to compare the means.

\section{Conclusion}

In conclusion, the phosphate and potassic rocks (hydroxyapatite and biotite) can be transformed by the interactive effect of the sulfur oxidizing bacteria $A$. thiooxidans, which was employed in continuous and crescent periods of incubation to produce biofertilizers from $\mathrm{P}$ and $\mathrm{K}$ rocks. In both biofertilizers with $\mathrm{P}$ and $\mathrm{K}$ rocks, sulfuric acid was produced after inoculation with $A$. thiooxidans, which reduced $\mathrm{pH}$ and released nutrients $(\mathrm{P}, \mathrm{Ca}$, $\mathrm{K}, \mathrm{Mg}$ and $\mathrm{S}$ ). Addition of sulfur in a level equivalent to $10 \%$ in relation to the amount of rocks is recommended to the reduction of cost. The biofertilizers produced from phosphate and potassic rocks showed potential to be applied as alternative for soluble PK fertilizers. The current study indicates the potential of phosphate and potassic rocks for use as biofertilizers, particularly for PK fertilization and to reduce environmental problems.

\section{Acknowledgements}

The authors are grateful to the CNPq - National Brazilian Scientific and Technological Development Council (Conselho Nacional de Desenvolvimento Científico e Tecnológico), to the FACEPE - Foundation for the Support of Science and Technology of the State of Pernambuco (Fundação de Amparo à Ciência e Tecnologia do Estado de Pernambuco), and to the CAPES - Coordination for the Improvement of Higher Education Personnel (Coordenação de Aperfeiçoamento de Pessoal de Nível Superior), by financial support and scholarships.

\section{References}

Araujo FF, Santos Jr J (2009) Nutrition and growth of maize in degraded soil biofertilized with natural phosphate, sulphur and Acidithiobacillus. Rev Caatinga. 22(1):98-103.

Barbosa Filho MP, Fageria NK, Santos DF, Couto PA (2007) Rochas brasileiras como fontes alternativas de potássio para a cultura do arroz de terras Altas. Boletim de Pesquisa e Desenvolvimento. Santo Antônio de Goiás: Embrapa Arroz e Feijão, 24p. 
Brown G, Brindley GW (1980) X-ray diffraction procedures for clay mineral identification. In: Brindley GW, Brown G (eds) Crystal Structures of Clay Minerals and Their X-Ray Identification. London, Mineralogical Society of Great Britain and Ireland. 5.

Dixon JB (1989) Kaolin and Serpentine group minerals. In: Dixon JB, Weed SB (eds) Minerals in soil environments, 2nd edn. Madison, Soil Science Society of America. 10.

Duarte IN, Sousa RTX, Korndorfer GH, Fontoura PR, Soares RAB (2012) Biotite: Potassium Source for agriculture. Biosci J. 28(1):98-103.

El Tarabily KA, Soaud AA, Saleh ME, Matsumoto S (2006) Isolation and characterization of sulfur-oxidizing bacteria, including strains of Rhizobium from calcareous sandy soils and their effects on nutrient uptake and growth of maize (Zea mays L.). Aust J Agr Res. 57:101111.

Embrapa - Empresa Brasileira de Pesquisa Agropecuária (2009) Manual de Análises Químicas de Solo, Plantas e Fertilizantes. 2nd edn. Brasília. 627.

Fink JR, Inda AV, Bavaresco J, Barrón V, Torrent J, Bayer C (2016) Adsorption and desorption of phosphorus in subtropical soils as affected by management system and mineralogy. Soil Till Res. 155:62-68.

Horta C (2015) Sustainability of phosphorus fertilisation: sources and forms of phosphate. Rev Ciênc Agrár. 38(4):473-483.

Kämpf N, Curi N, Marques JJ (2009) Óxidos de alumínio, silício, manganês e titânio. In: Melo VF, Alleoni LRF (eds) Química e mineralogia do solo Parte I- Conceitos básicos, 1st edn. Viçosa, Brazilian Soil Science Society. 9.

Klein CPAT, Blieck-Hogemerst JMA, Wolket JGC, Groot K (1990) Studies of the solubility of different calcium phosphate ceramic particles in vitro. Biomaterials. 11(7):509-512

Lima FS, Stamford NP, Sousa CS, Lira Jr MA, Malheiros SMM, van Straaten P (2010) Earthworm compound and rock biofertilizer enriched in nitrogen by inoculation with free living diazotrophic bacteria. World J Microb Biot. 26:1769-1777.

Lima RCM, Stamford NP, Santos CERS, Dias SHL (2007) Lettuce yield and chemical attributes of an Oxisol by application of biofertilizers from phosphate and potash rocks. Hortic Bras. 25:224-229.

Melo VF, Castilhos RMV, Pinto LFS (2009) Reserva Mineral do Solo. In: Melo VF, Alleoni LRF (eds) Química e mineralogia do solo Parte I- Conceitos básicos, 1st edn. Viçosa, Brazilian Soil Science Society. 4.

Moore DM, Reynolds Jr. RC (1989) X-ray diffraction and the identification and analysis of clay minerals. New York. 332.

Oliveira FLN, Oliveira WS, Stamford NP, Silva EVN, Santos CERS, Freitas ADS (2017) Effectiveness of biofertilizer enriched in $\mathrm{N}$ by Beijerinckia indica on sugarcane grown on an Ultisol and the interactive effects between biofertilizer and sugarcane filter cake. J Soil Sci Plant Nutr. 17(4):1040-1057.
Oliveira WS, Stamford NP, Silva EVN, Santos CERS, Freitas ADS, Arnaud TMS, Sarmento BF (2014) Biofertilizer produced by interactive microbial processes affects melon yield and nutrients availability in a Brazilian semiarid soil. Aust J Crop Sci. 8(7):1124-1131.

Santos HC, Oliveira FHT, Souza AP, Salcedo IH, Silva VDM (2016) Phosphorus availability as a function of its time of contact with different soils. Rev Bras Eng Agríc Ambient. 20(11):996-1001.

Santos WO, Mattiello EM, Costa LM, Abrahão WAP (2015) Characterization of verdete rock as a potential source of potassium. Rev Ceres. 62(4):392-400.

Santos MF (2013) Sistemas baseados em amido termoplástico: pectina contendo hidroxiapatita nanoestruturada visando liberação de fósforo em meio aquoso. Master's Thesis (Master's degree in Biotechnology) - University Federal of São Carlos, São Paulo, 65p.

SAS Institute (2011) The SAS 9.2 software. System for Windows. CD-ROM for Windows.

Silva Jr S, Stamford NP, Oliveira WS, Silva EVN, Santos CERS, Freitas ADS, Silva VSG (2018) Microbial biofertilizer increases nutrient uptake on grape (Vitis labrusca L) grown in an alkaline soil reclaimed by sulfur and Acidithiobacillus. Aust J Crop Sci. 12(10):1695-1701.

Soares WV, Lobato E, Sousa DMG, Rein TA (2000) Evaluation of a coarse-ground Gafsa rock phosphate in the recuperation of a degraded pasture on a clayey dark-red latosol. Pesq Agropec Bras. 35(4):819-825.

Stamford NP, Simões Neto DE, Freitas ADS, Oliveira ECA, Oliveira WS, Cruz L (2016) Rock biofertilizer and earthworm compost on sugarcane performance and soil attributes in two consecutive years. Sci Agric. 73(1):29-33.

Stamford NP, Figueiredo MVB, Silva Jr S, Freitas ADS, Santos CERS, Lira Jr MA (2015) Effect of gypsum and sulfur with Acidithiobacillus on soil salinity alleviation and on cowpea biomass and nutrient status as affected by PK rock biofertilizer. Sci Hort. 195:287-292.

Stamford NP, Silva Jr S, Santos CERS, Freitas ADS, Santos CMA, Arnaud TMS, Soares HR (2014) Yield of grape (Vitis labrusca cv. Isabel) and soil nutrients availability affected by biofertilizer with diazotrophic bacteria and fungi chitosan. Aust J Crop Sci. 8(2):301-306.

Stamford NP, Silva Jr S, Santos CERS, Freitas ADS, Lira Jr MA, Barros MFC (2013) Cowpea nodulation, biomass yield and nutrient uptake, as affected by biofertilizers and rhizobia, in a sodic soil amended with Acidithiobacillus. Acta Sci Agron. 35(4):453-459.

Stamford NP, Andrade IP, Silva Jr S, Lira Jr M, Santos CS, Freitas AS, van Straaten P (2011) Soil properties and grape yield affected by rock biofertilisers with earthworm compound. J Soil Sci Plant Nutr. 11(4):1525.

Stamford NP, Moura PM, Lira Jr MA, Santos CERS, Duenhas LH, Gava CAT (2009) Chemical attributes of an Argisoil of the Vale do São Francisco after melon growth with phosphate and potash rocks biofertilizers. Aust J Crop Sci. 27(4):447- 452. 
Stamford NP, Santos CERS, Stamford Jr WP, Dias SL (2004) Biofertilizantes de rocha fosfatada com Acidithiobacillus como adubação alternativa de caupi em solo com baixo P disponível. Anal J. 9:48-53.
Van Straaten P (2007) Agrogeology: the use of rocks for crops. Cambridge. Ontario. 426. 